\title{
Inverted terminal repeats from adeno-associated virus- 2 enhance the expression of the chimeric E2 glycoprotein gene of classical swine fever virus
}

\author{
Ia. O. Pokholenko, P. V. Buchek, M. V. Drahulian, V. A.Kordium \\ Institute of Molecular Biology and Genetics, NAS of Ukraine \\ 150, Akademika Zabolotnoho Str., Kyiv, Ukraine, 03143 \\ yasnenka@gmail.com
}

\begin{abstract}
Aim. To assess the effect of insertion of inverted terminal repeats from human adeno-associated virus-2 into plasmid vector on the expression of the chimeric E2 glycoprotein gene of classical swine fever virus and immunogenicity of the developed candidate marker DNAvaccines against classical swine fever. Methods. Confocal laser scanning microscopy, fluorescence-activated cell sorting and western blot analysis were used to study chimeric protein expression in HEK293 cells. The antibodies specific to E2 of classical swine fever virus were detected by ELISA. Results. We show that the insertion of inverted terminal repeats into a plasmid vector results in considerable enhancement of the chimeric E2 expression in HEK293 in vitro. At the same time, it does not significantly influence in vitro transgene retention. The vector containing inverted terminal repeats from human adeno-associated virus- 2 elicits antiE2 antibodies titer significantly higher as compared to the initial vector without repeats. Conclusions. The insertion of inverted terminal repeats from human adeno-associated virus-2 into the candidate marker DNA-vaccine against classical swine fever results in a significant increase of the chimeric transgene expression and humoral immune response.
\end{abstract}

Keywords: marker DNA-vaccine, classical swine fever, ITR AAV-2, humoral immune response

\section{Introduction}

Classical swine fever (CSF) is a highly contagious viral disease of Suidae family species listed by World organization of animal health. It is caused by classical swine fever virus (CSFV), belonging to the family Flaviviridae, genus Pestivirus [1]. Due to high morbidity, mortality, and trade restrictions, the disease causes substantial economic losses for global pork industry [2]. Despite the recent improvement of epizootic situation regarding CSF, there is a constant threat of new outbreaks due to the circulation of the virus in wild boar

(C) 2021 Ia. O. Pokholenko et al.; Published by the Institute of Molecular Biology and Genetics, NAS of Ukraine on behalf of Biopolymers and Cell. This is an Open Access article distributed under the terms of the Creative Commons Attribution License (http://creativecommons.org/licenses/by/4.0/), which permits unrestricted reuse, distribution, and reproduction in any medium, provided the original work is properly cited 
populations in countries endemic for the disease. The main preventive measures against CSF are vaccination or complete elimination of infected and potentially infected livestock and a vaccination ban. The latter is used because no licensed attenuated viral vaccines against CSF, despite their high protective efficiency, do not allow discriminating infected and vaccinated animals serologically [2]. Two marker vaccines against CSF based on E2 glycoprotein have been licensed (Bayovac ${ }^{\circledR}$ CSF Marker (Bayer, Germany) and Porcilis ${ }^{\circledR}$ pesti (Intervet International $\mathrm{BV}$, The Netherlands)). However, these vaccines could not completely block vertical transmission of CSFV, and their protection period was shorter than for attenuated viral vaccines [2]. Thus, the problem of developing effective marker vaccine against CSF and respective diagnostic system, that allows serological discrimination of vaccinated versus infected animals, remains unsolved.

DNA vaccination is based on the administration of a plasmid DNA vector-containing gene encoding the protective antigen, which provides the antigen expression in host cells and elicits protective immunity against the pathogen. The advantages of DNA vaccines include their ability to induce both humoral and cellular immune responses, relatively low cost of manufacturing, temperature stability, and the possibility of rapid modification of the initial constructs [3]. Previously, we described the candidate marker DNA-vaccine against CSF based on the fragment of a gene of E2 glycoprotein of CSFV, in eukaryotic expression cassette, placed between inverted terminal repeats (ITRs) from human adeno-associated virus-2 (AAV-2) [4]. We also demonstrated that the immunization of mice with constructed recombinant vector elicited humoral immune response to chimeric E2 protein. However, several important issues directly related to the influence of ITR from AAV-2 on the target antigen expression level, transgene retention, and the dynamics of humoral immune response remained beyond the scope of the research. Nevertheless, the mentioned issues are critically important for characterization of the candidate vaccine properties and its safety profile.

The aim of the present study is to assess the effect of internal terminal repeats from the human adeno-associated virus- 2 insertion into plasmid vector on the chimeric E2 glycoprotein CSFV synthesis in vitro, duration of transgene retention, and immunogenicity of the developed candidate marker DNA-vaccine against CSF in mice.

\section{Materials and Methods}

Expression plasmids, subcloning and bacterial strains. The strains of Escherichia coli Sure ${ }^{\circledR} 2$ (Stratagene, USA), DH10B (Life Technologies, USA), and BL 21 (DE3) (Novagen, Germany) were used. Vector pTRUF was a gift from S. Zolotukhin (U.F. Gene Therapy Center Vector Core Lab, USA). Vectors pTR-BKneo-, and pET24ap-csfv@rev were previously described [4]. Plasmid DNA for transfection and immunization was prepared according to the protocol described in [5]. Vector pBS-BK was constructed by subcloning the BglII fragment of pTR-BKneointo pBluescript SK(-) in the BamHI recogni-

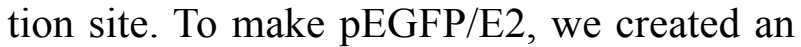
intermediate construct $\mathrm{p} 2 \mathrm{EGFP}-\mathrm{C} 1$ by subcloning NheI/SmaI fragment of pEGFP-C1 into pEGFP-N2 treated with NheI/SmaI. pEG- 
FP/E2 was created by subcloning SmaI/NotI fragment of pET24ap-csfv@rev into p2EGFP$\mathrm{C} 1$ treated with the same enzymes. Vector pTR-EGFP/E2 was created by subcloning NheI/NotI fragment of pEGFP/E2 into pTRUF treated with the same enzymes. Plasmid vector $\mathrm{pET} 24-\mathrm{EGFP}$ for the recombinant EGFP expression in E.coli strain BL21 (DE3) was constructed by subcloning EcoRI/NotI fragment of pEGFP-N2 into pET24(+) (Novagen) treated with the same enzymes.

Antibodies. Recombinant EGFP for immunization of rabbits was obtained by expression of the protein in the E.coli strain BL21(DE3) transformed by pET24-EGFP according to the standard protocol [6]. The protein was purified by column chromatography using DEAE Sepharose, Phenyl Sepharose, and Sephadex G-25 resigns (GE Healthcare) according to the manufacturer's protocols. Rabbits $(2.5-3 \mathrm{~kg})$ were injected intramuscularly with $0.85 \mathrm{mg}$ of purified recombinant protein emulsified in complete Freund's adjuvant (Sigma-Aldrich, USA). On the 14th day, animals were injected with $0.85 \mathrm{mg}$ of antigen emulsified in incomplete Freund's adjuvant, followed by booster immunization with the same amount of protein one week later. Seven days after the boost, the serum antibody titer was tested using ELISA.

Cultivation of HEK293 and transfection. The HEK293 cell line was obtained from the Russian cell culture collection. The cells were cultured in a DMEM culture medium containing $10 \%$ fetal calf serum, $100 \mathrm{U} / \mathrm{ml}$ of penicillin, and $100 \mu \mathrm{g} / \mathrm{ml}$ of streptomycin at $+37^{\circ} \mathrm{C}$, $5 \% \mathrm{CO}_{2}$. The cells were transfected using $25-\mathrm{kDa}$ branched polyethylenimine (PEI) (Sigma-Aldrich, USA) as described in [7]. For the MTT assay, HEK293 were detached from culture plastic for transfection by exposure to $0.25 \%$ trypsin- $0.02 \%$ EDTA for 5 min. Cells were pelleted by centrifugation $1.2 \times 10^{3} \mathrm{rpm}$ for $7 \mathrm{~min}$, and obtained pellets were washed with DMEM medium three times. Then, $3 \times 10^{5}$ cells were resuspended in $0.15 \mathrm{~mL}$ fresh medium. The $\mathrm{pDNA} / \mathrm{PEI}$ complex formation was performed as described in [7]. The pDNA/PEI complexes were diluted by new DMEM medium to $0.85 \mathrm{~mL}$ and added to the cells suspension. The cells were collected by centrifugation $1.2 \times 10^{3} \mathrm{rpm}$ for $7 \mathrm{~min}$ after 1 hour of incubation at $+37{ }^{\circ} \mathrm{C}, 5 \% \mathrm{CO}_{2}$. The pellets were resuspended in complete fresh medium and seeded into a 96-well cell culture plate with seeding density $-15 \times 10^{3}$ cells /well.

MTT assay. The influence of transfection procedure and expression of the transgene on the viability of HEK293 was tested in MTTassay. The MTT-assay was performed 24 and 72 hours after transfection according to the method described in [8]. Each point was performed in triplicate.

FACS analysis. Expression of EGFPtagged proteins was assayed $48-72$ hours after transfection by fluorescence-activated cell sorting (FACS). The analysis was performed on BD FACSAria ("Becton Dickinson," USA), using BD FACSDiva software.

Confocal microscopy. Confocal laser scanning microscopy (CLSM) analysis was done using Leica TCS SPE Confocal system with coded DMi8 inverted microscope (Leica, Germany). Twenty-four hours after transfection, the cells were fixed in $4 \%$ paraformaldehyde in PBS for $10 \mathrm{~min}$, according to the method described in [9]. Counterstaining was performed with Hoechst 33342 and Nile Red 
according to the protocols described in [10, 11]. Images were acquired using excitation at $488 \mathrm{~nm}$ and emission collected at 509-588 for EGFP, excitation at $405 \mathrm{~nm}$ and emission collected at 415-468 for Hoechst 33342, and excitation at $532 \mathrm{~nm}$ and emission collected at 607-761 for Nile Red.

In vitro protein expression (Western blot). At different time points, cells were harvested, and lysates were prepared using RIPA cell lysis buffer containing $1 \mathrm{mM}$ PMSF. Proteins were separated in $13 \%$ SDS-PAGE, followed by the semi-dry transfer; membranes were blocked by incubation in $3 \%$ solution of skimmed milk in PBS containing $0.1 \%$ Tween-20. Then the membranes were washed in PBS, and incubated with anti-EGFP polyclonal antibodies (working dilution 1:1000), developed as described above, then visualized with horseradish peroxidase-conjugated anti-rabbit IgG (Sigma). Following ECL detection, each blot was stained using Amido Black as described in [12].

Immunization. The experiments were conducted on female mice of BALB/c line (breeding of IMBG, NAS of Ukraine), 2-2.5 months old. All the manipulations with animals were performed using sedative and anesthetic preparations in compliance with the requirements of veterinary legislation. For immunogenicity studies, on days $0,14,28$, mice were administered with $100 \mu \mathrm{g}$ of each pDNA vector studied to the biceps muscle. An equal amount of pTR-UFneo- was administered to mice of a control group. The blood for isolation of serum was obtained by retro-orbital puncture.

ELISA. The antibodies, specific to E2 CSFV in murine blood serum, were detected by ELISA according to [4]. The results are presented as the average value of reciprocal titer \pm statistically average deviation $(n=7$ in each group).

Detection of the CSFV E2 gene fragment and egfp by PCR. The total DNA from HEK293 cells and biceps tissue was extracted according to the protocol [13]. Detection of the $E 2$ gene fragment was performed as described earlier [4]. To detect egfp a pair of primers was designed: EGFP fr- 5'-GTCACTAGTATGGT GAGCAAGGGCGAGGA-3' and EGFP rev5'-GTCCTGCAGCTACTCGTCCATGCCGA GAGTGA-3'. The reaction mixture contained $100 \mathrm{ng}$ of total DNA. The amplification of the egfp was conducted on DNA-amplifier Tercik (DNA-technologies, RF) using the following scheme: DNA denaturation $-95^{\circ} \mathrm{C}, 300 \mathrm{sec}$; annealing of primers $-63.9^{\circ} \mathrm{C}, 60 \mathrm{sec}$; elongation $-72{ }^{\circ} \mathrm{C}, 60 \mathrm{sec}$, for one cycle, followed by 30 cycles: DNA denaturation $-95^{\circ} \mathrm{C}$, $300 \mathrm{sec}$; annealing of primers $-61.8^{\circ} \mathrm{C}$, $30 \mathrm{sec}$; elongation $-72{ }^{\circ} \mathrm{C}, 60 \mathrm{sec}$. After the process, the amplification products were separated by electrophoresis in $0.8 \%$ agarose gel.

Statistics. All statistical analyses were performed using MaxStat Pro 3.6 software. To assess the significance of the discrepancies, we used the non-parametric criterion of MannWhitney (U) and two-sample t-test to compare FACS-analysis data.

\section{Results and Discussion}

Although DNA vaccine development technology offers a rapid elaboration of a novel vaccine, only three DNA vaccines have been licensed since 1993 for veterinary use [14]. India has approved the world's first DNA vaccine for human use in 2021. The DNA SARSCoV-2 vaccine (ZyCoV-D), produced by Zydus Cadila, received authorization for emergency 
use for people aged 12 and older from the Central Drugs Standard Control Organization on 20th August, 2021 [15]. Additionally, several candidate DNA vaccines against COVID-19 and other diseases are currently undergoing clinical trials. The main problems identified in clinical trials of candidate DNA vaccines were: low transfection efficiency of human cells in vivo, low immunogenicity, and the need to administer high doses of plasmid DNA. One of the possible directions to increase the immunogenicity of a DNA vaccine is to increase the level of the target antigen expression. This can be done by selecting appropriate strong non-tissue-specific promoters and enhancer elements to modify the DNA construct. It has been demonstrated that the introduction of inverted terminal repeats from human adeno-associated virus- 2 into expression vector enhanced the expression of HIV Env, gp55 Gag, herpes simplex virus type 2 glycoproteins $\mathrm{B}$ and $\mathrm{D}, \beta$ - galactosidase, and immunogenicity of correspondent candidate DNA-vaccines [16-19]. Additionally, it has been shown that the ITR from AAV-2 exhibited promoter activity [20]. However, the ITR's
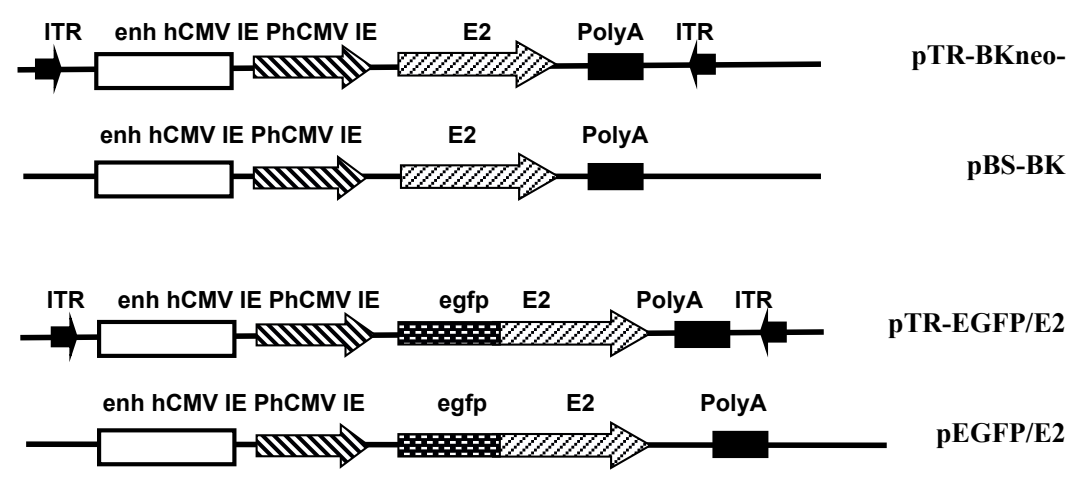
analysis.
pTR-BKneo-

pBS-BK

EGFP/E2

effect on the expression of chimeric E2 glycoprotein CSFV has not been studied.

Recently, we have described the eukaryotic expression vector $\mathrm{pTR}-\mathrm{BKneo}^{-}$encoding the fragment of the CSFV E2 glycoprotein gene placed under the regulation of early-immediate promotor of human cytomegalovirus, located between ITRs of AAV-2 [4]. In the present work, we constructed recombinant plasmid pBS-BK that has the same genetic elements except ITRs (Fig. 1). We also created recombinant vectors containing chimeric genes encoding EGFP and E2 fusion protein (pTR$\mathrm{EGFP} / \mathrm{E} 2$ and $\mathrm{pEGFP} / \mathrm{E} 2)$ to perform in vitro studies with the transient transfection (Fig. 1). The reporter system based on EGFP allows monitoring protein expression in living cells to estimate the transfection efficiency by FACS

CLSM analysis performed 24 hours after transfection revealed the expression of EGFPfused protein in HEK293 cells transfected with pTR-EGFP/E2 or pEGFP/E2 (Fig. 2 A). The analysis revealed also significant differences in the intracellular localization of the chimeric proteins compared to the distribution well

Fig. 1. Schematic representation of the recombinant plasmids pTRBKneo-, pBS-BK, pTR-EGFP/E2, and $\mathrm{pEGFP/E2:} \mathrm{ITR} \mathrm{-} \mathrm{inverted} \mathrm{ter-}$ minal repeats AAV-2; enh hCMV human cytomegalovirus immediateearly enhancer; PhCMV - human cytomegalovirus immediate-early promoter; E2 - SacI-EcoRI-fragment of E2 CSFV gene; egfp cDNA of Enhanced Green Fluorescent Protein A.victoria; Poly A a signal of polyadenylation. 


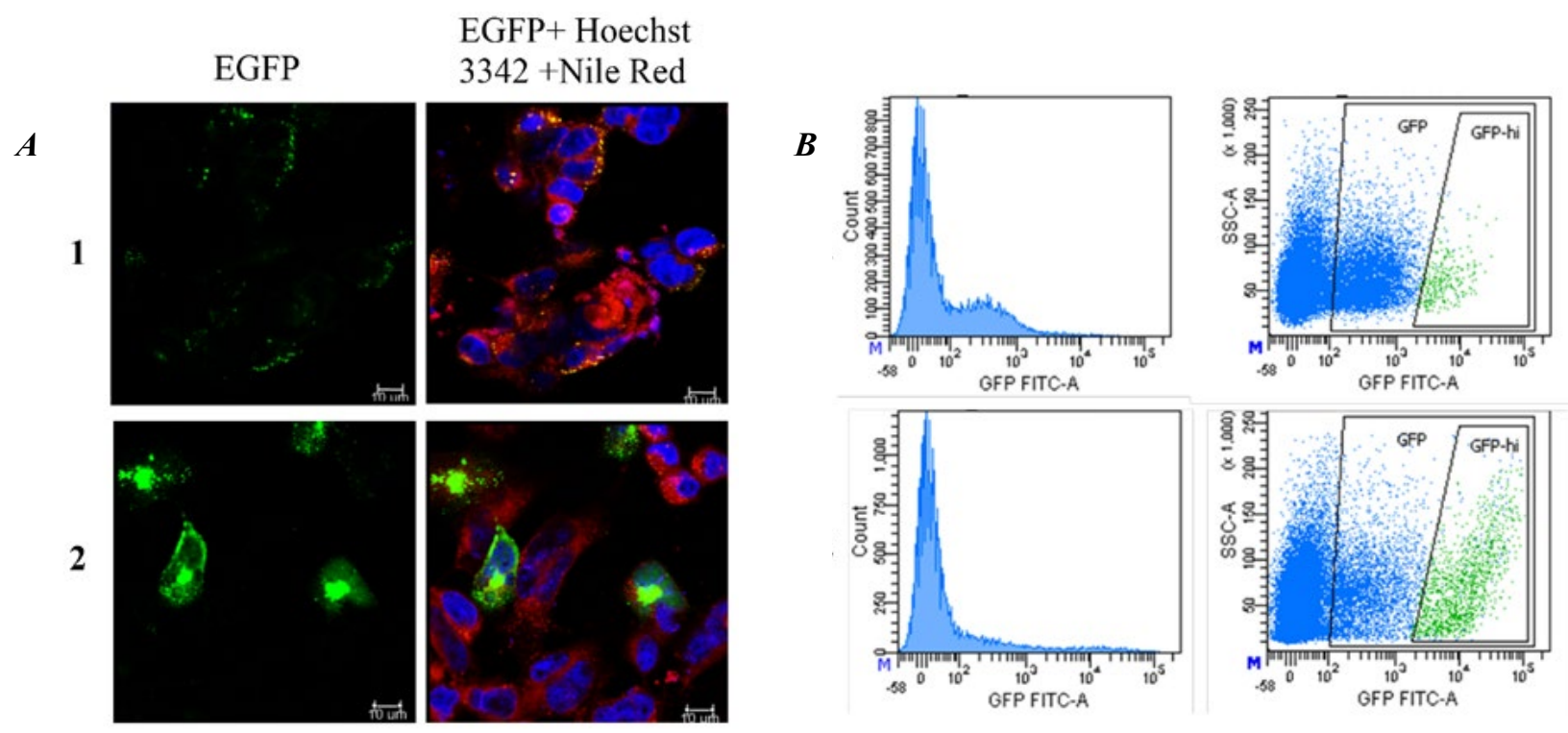

Fig. 2. $A-$ CLSM image of HEK293 cells expressing EGFP/E2, 24 hours after transfection with pEGFP/E2 (1) or pTR-EGFP/E2 (2), (counterstaining with Hoechst 3342 and Nile Red, bar - 10 $\mu \mathrm{m}$ ). B - FACS analysis of EGFP/E2 expression in HEK293 cells, 72 hours after transfection with pEGFP/E2 (1) or pTR-EGFP/E2 (2). The figures are representatives of 3 independent experiments in each variant.

known for unmodified EGFP. In contrast to the known uniform diffuse distribution of EGFP within the cytoplasm of the cell and accumulation of this protein in the structures of the nucleus, all chimeric EGFP/E2 proteins were located outside the nucleus of transfected cells, in the form of individual granular structures in the cytoplasm. The predominant localization of the granules in the perinuclear space may indicate the accumulation of chimeric glycoproteins in the endoplasmic reticulum and the Golgi apparatus during posttranslational modification (Fig 2.A2). Noteworthy, E2 can be involved in the endoplasmic reticulum stress (ERS)mediated autophagy, induced by CSFV in the host cell for sustaining virus replication both in vivo and in vitro [21]. Besides, it has been shown that E2 can interact with a wide range of host proteins such as actin, thiredoxin, an- nexin 2 , dynactin 6 , mitogen-activated protein kinase 2, SERTA domain containing protein 1, etc. [22]. The data obtained by FACS-analysis revealed that the number of cells with a high fluorescence intensity was significantly higher in pTR-EGFP/E2 transfected cells $41.9 \pm 13.1 \%$ (of the total cell number) (Fig. 2 B) than in pEGFP/E2 transfected cells $-8 \pm 3.3 \%$. This indicates an increase of EGFP/E2 protein synthesis in cells transfected with pTR-EGFP/E2.

Further analysis of transfected cell lysates by western blot confirmed the presence of EGFP/E2 chimeric protein. The molecular weight of the main protein band detected by western blot was about $68.5 \mathrm{kDa}$ (Fig.3 A). However, the theoretical molecular weight of the EGFP/E2 protein corresponds to $57.8 \mathrm{kDa}$. The observed discrepancy could be explained by the presence of glucans in the five potential 


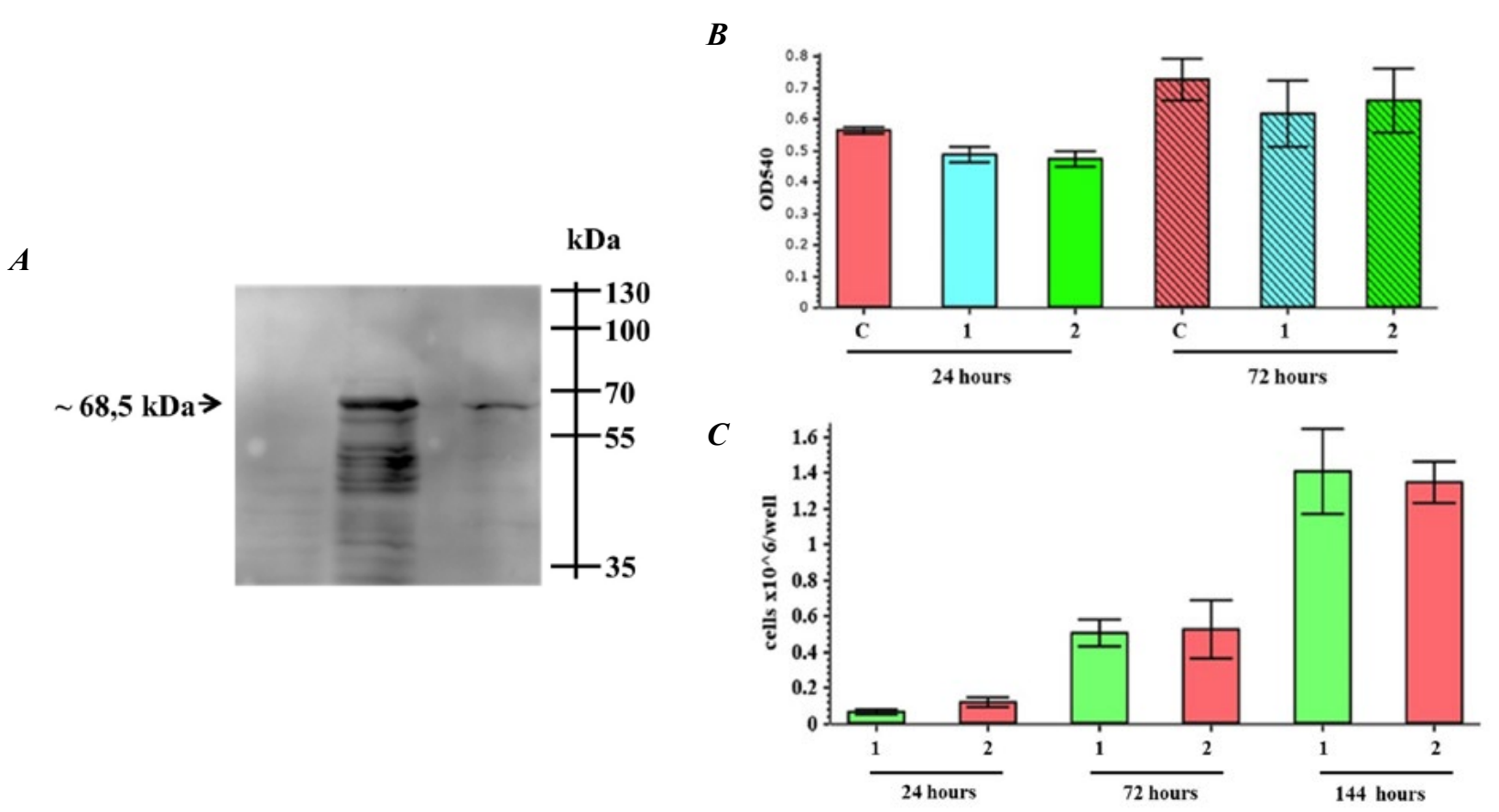

Fig. 3. $A, B-$ EGFP/E2 expression detected in HEK 293 cells lysates by Western blot, 72 hours after transfection: A: 1 - HEK293; 2 - lysate of cells transfected with pTR-EGFP/E2; 3 - molecular weight marker \#26619 (Thermo Scientific); 4 - lysate of cells transfected with pEGFP/E2; B - Viability of cells transfected with pTR-EGFP/E2 (1) and pEGFP/E2 (2) measured by MTT assay; (C - control HEK293 cells); C-Cell proliferation assay. Cell counts at three different time points $(24,72$, and 144 hours) after transfection of HEK293 cells with pEGFP/E2 (1) or pTREGFP/E2 (2). The figures are representatives chosen from 3 independent experiments in each variant.

$\mathrm{N}$-glycosylation sites located on the part of the E2 protein used for the study [23]. A similar shift of the molecular weight of this E2 glycoprotein fragment has been described previously [4] and for a chimeric protein based on the fulllength E2 glycoprotein in [24]. Thus, the band detected between $68.5 \mathrm{kDa}$ and $57.8 \mathrm{kDa}$ in the lysates of cells transfected by pTR-EGFP/E2 can be explained by partial glycosylation and the bands with molecular weight lower than $57.8 \mathrm{kDa}$ - by protein degradation. The amount of EGFP/E2 in the cells transfected with plas$\mathrm{mid}$ pTR-EGFP/E2 was $113 \pm 21 \mathrm{ng} / 10^{5}$ cells $/ 72 \mathrm{~h}$, while transfecting cells with plasmid $\mathrm{pEGFP} / \mathrm{E} 2$ was $15 \pm 3 \mathrm{ng} / 10^{5}$ cells/72 h.
We also performed cell viability and proliferation assays to define whether the observed difference in magnitude of the chimeric protein expression was not due to cytotoxic effects of DNA/PEI complexes [25]. The data obtained in MTT- and cell counts assays did not reveal any significant differences in cell viability and proliferation rates between the cell populations transfected with the indicated vectors (Fig. 3B, C). Thus, the obtained results show that the difference in the expression levels of the chimeric protein EGFP/E2 is not due to the inhibition of the metabolic activity of cells or higher cytotoxicity of the pEGFP/E2 and PEI complexes. 
$A$

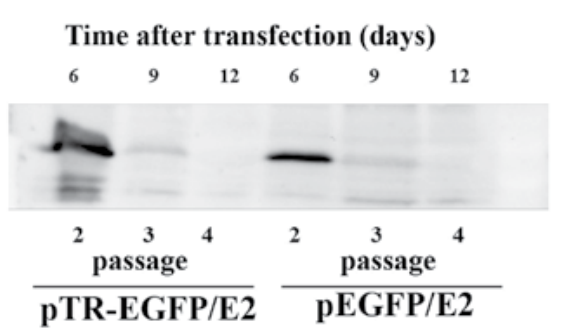

$\boldsymbol{B}$

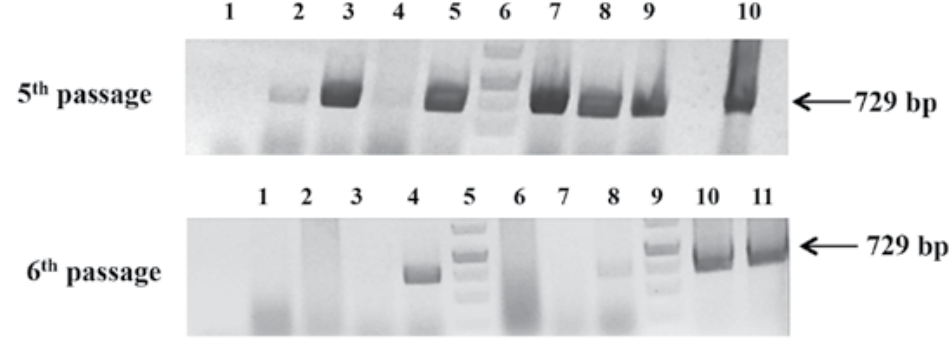

Fig. 4. $A$ - Western blot analysis of EGFP/E2 expression in HEK293 cells. HEK293 cells were transfected with pTREGFP/E2 or $\mathrm{pEGFP/E2}$. Cells were harvested at the indicated time points or passaged every three days. Cell lysates obtained from $5 * 10^{4}$ cells were subjected to western immunoblot analyses using polyclonal antibodies against EGFP. $B$ - The electrophoregram of PCR products, obtained using primers EGFP fr and EGFP rv: $5^{\text {th }}$ passage $-1-$ negative control (total DNA from HEK293 cells); 2-5 - samples of total DNA extracted from HEK293 transfected with pTR-EGFP/E2; 6 - molecular weight marker O 'GeneRuler 1kb (Fermentas); 7-9 - samples of total DNA extracted from HEK293 transfected with $\mathrm{pEGFP} / \mathrm{E} 2 ; 10$ - positive control (pTR-EGFP/E2). $\mathbf{6}^{\text {th }}$ passage -1 - negative control (total DNA from HEK293 cells); 2-4 - samples of total DNA extracted from HEK293 transfected with pTR-EGFP/E2; 5, 10 - molecular weight marker O 'GeneRuler 1kb (Fermentas); 6-8 - samples of total DNA extracted from HEK293 transfected with pEGFP/E2; 10 - positive control (pTR-EGFP/E2); 11 - positive control (pEGFP/E2). The PCR products are indicated by an arrow.

The EGFP/E2 expression stability and duration of transgene retention in vitro were checked under non-selective conditions to mimic in vivo situation more closely. The initial transfection efficiency was monitored by FACS-analysis. The examined cell populations had similar amounts of EGFP positive cells 72 hours after transfection. The western blot analysis revealed that the EGFP/E2 expression was not detected in cell lysates after the fourth passage (the cells split ratio during passaging was 1:2) (Fig. 4, A). At the same time, the transgene was detected by PCR at least till the $6^{\text {th }}$ passage in the cells transfected by pTR-EGFP/E2 or by pEG$\mathrm{FP} / \mathrm{E} 2$, but not in all samples of the same variant (Fig. 4B). Thus, we conclude that the introduction of ITR from AAV-2 into plasmid vector does not significantly influence transgene persistence in vitro in these conditions.

We also compared the immunogenicity of pTR-BKneo- and pBS-BK in mice. The ob- tained results revealed that the level of antigenspecific antibodies was significantly higher in mice injected with pTR-BKneo- (Fig. 5A). This group also was highly seropositive for a more extended period. PCR analysis of total DNA extracted from muscle tissues in a place of injection revealed prolonged retention of the transgene in the pTR-BKneo- group (Fig. 5, $\mathrm{B} 1$ and $\mathrm{B} 2$ ). The transgene was detected in $40 \%$ of samples taken 74 days after the first immunization. All samples from mice injected with pBS-BK were found to be negative to this date. The longer persistence of ITR containing vectors can be explained by their long-term episomal retention as concatemers in skeletal muscle cells as described in [26].

\section{Conclusions}

Summarizing the obtained data, we conclude that the insertion of ITRs from human AAV-2 into plasmid vectors containing chimeric E2 glyco- 

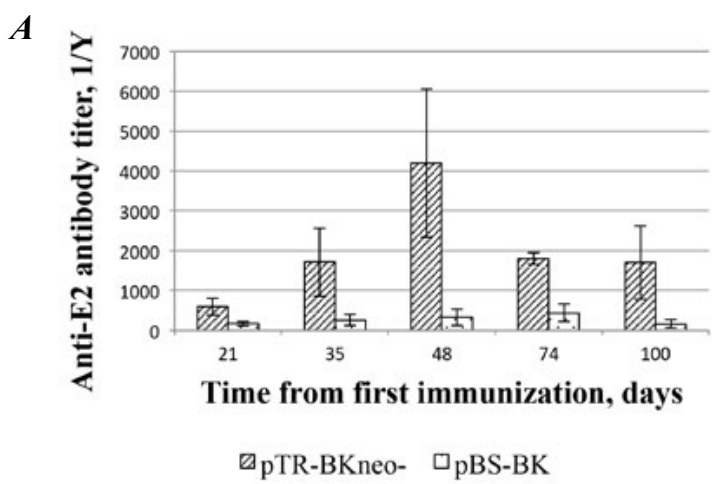

$B$

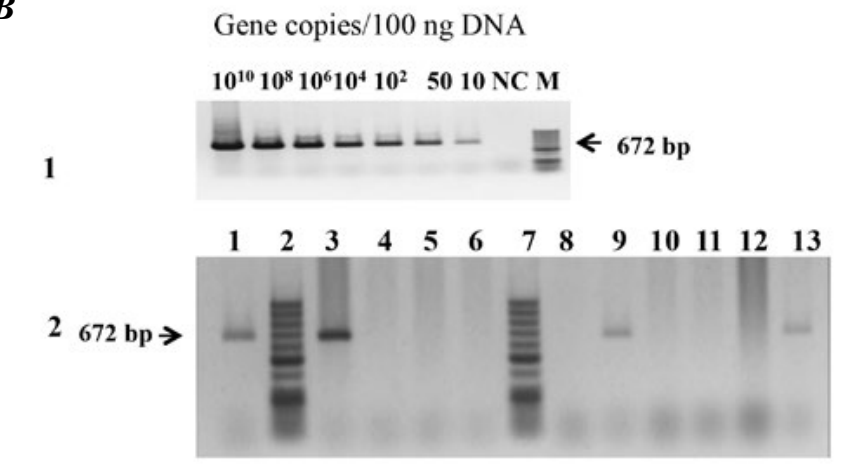

Fig. 5. A - Antibody titer changing in mice after immunization with pTR-BKneo- or pBS-BK. B1 — Determination of the detection limit of E2 fragment using PCR and serial dilutions of pTR-BKneo-. Each sample contained $100 \mathrm{ng}$ of total DNA extracted from murine biceps. Input pDNA dilutions are indicated above the lane. NC - negative control (total DNA-sample without adding pDNA); $\mathrm{M}$ - molecular weight marker O`GeneRuler 50bp DNA Ladder (Fermentas). The size of PCR products is indicated with an arrow. B2 - Agarose gel electrophoresis of the PCR products, obtained using primers E2sn and E2asn: 1 - total DNA extracted from murine biceps, 48 days after injection of pBS-BK; 3 - total DNA extracted from murine biceps, 48 days after injection of pTR-BKneo-; 4-6 - total DNA extracted from murine biceps, 74 days after injection of pBS-BK; 2,7 - molecular weight marker O GeneRuler 50bp DNA Ladder (Fermentas); 8 - total DNA extracted from murine biceps of control group injected with pTRUFneo-; 9-13 - total DNA extracted from murine biceps, 74 days after injection of - pTR-BKneo. The size of PCR products is indicated with an arrow.

protein gene of CSFV leads to a significant increase in chimeric protein accumulation in HEK293 cells 72 hours after transfection. At the same time, there was no increase of transgene persistence in vitro as compared with the vector without ITRs. The considerable rise in the magnitude of the humoral immune response and prolonged transgene retention in vivo were observed after immunization of mice with pTR-BKneo-.

\section{Acknowledgments}

The authors thank Dr. O.V. Moshynets and Dr. V. M. Kyryk for their valuable support of the project.

\section{REFERENCES}

1. Ganges L, Crooke HR, Bohórquez JA, Postel A, Sakoda Y, Becher P, et al. Classical swine fever virus: the past, present and future. Virus Research. 2020;289:198151.

2. Coronado L, Perera CL, Rios L, Frías MT, Pérez $L J$. A Critical Review about Different Vaccines against Clas-sical Swine Fever Virus and Their Repercussions in Endemic Regions. Vaccines. 2021;9(2):154.

3. Gary $E N$, Weiner $D B$. DNA vaccines: prime time is now. Current Opinion in Immunology. $20201 \mathrm{Au}-$ gust;65:21-7.

4. Pokholenko IA, Ruban TA, Sukhorada OM, Deriabin OM, Tytok TG, Kordium VA. The development of DNA-vaccine against classical swine fever. Biopolym Cell. 2007;23(2):93-9.

5. Current protocols in molecular biology, Eds $M$ Ausubel, R Brent, RE Kingston, DD Moore, JG Seidman, JA Smith, K Struhl. John Wiley \& Sons, Inc, 1997;1: 1.7.9-1.7.10.

6. Molecular cloning. A laboratory manual by T. Maniatis, E F Fritsch and J Sambrook. 2nd ed.Cold Spring Harbor Laboratory, New York. 1989. 625p 
7. Toporova OK, Novikova SN, Lihacheva LI, Suhorada OM, Ruban TA, Kozel JA, et al. Non-viral gene delivery of human apoA1 into mammalian cells in vitro and in vivo. Biopolym Cell. 2004;20(1-2):25-32.

8. Denizot $F$, Lang $R$. Rapid colorimetric assay for cell growth and survival. Modifications to the tetrazolium dye procedure giving improved sensitivity and reliability. J Immunol Methods. 1986;89(2):271-7.

9. Baumstark-Khan C, Palm M, Wehner J, Okabe M, Ikawa M, Horneck G. Green Fluorescent Protein (GFP) as a Marker for Cell Viability After UV Irradiation. J Fluoresc. 1999; 9(1):37-43.

10. Chazotte B. Labeling Nuclear DNA with Hoechst 33342. Cold Spring Harbor Protocols. 2011;2011(1): pdb.prot5557.

11. Greenspan P, Mayer EP, Fowler SD. Nile Red: a selective fluorescent stain for intracellular lipid droplets. The J Cell Biol. 1985; 100(3):965-73.

12. Aldridge GM, Podrebarac DM, Greenough WT, Weiler IJ. The use of total protein stains as loading controls: an alternative to high-abundance single protein controls in semi-quantitative immunoblotting. J Neurosci Methods. 2008;172(2):250-4.

13. Lowrie $D B$, Whalen $R$, editors. DNA vaccines: methods and protocols. Humana Press; 2000. (Methods in Molecular Medicine). https://www.springer. com/gp/book/9780896035805

14. Williams JA. Vector design for improved DNA vaccine efficacy, safety and production. Vaccines ( $\mathrm{Ba}$ sel). 2013;1(3):225-49.

15. Mallapaty $S$. India's DNA COVID Vaccine Is a World First - More Are Coming. Nature. 2021; 597(7875):161-62.

16. Xin K-Q, Ooki T, Jounai N, Mizukami H, Hamajima K, Kojima $Y$, et al. A DNA vaccine containing inverted terminal repeats from adeno-associated virus increases immunity to HIV. J Gene Med. 2003;5(5):438-45.

17. Manning WC, Paliard X, Zhou S, Pat Bland M, Lee AY, Hong $K$, et al. Genetic immunization with adeno-associated virus vectors expressing herpes simplex virus type 2 glycoproteins B and D. J Virol. 1997;71(10):7960-2.

18. Marques ETA, Chikhlikar P, de Arruda LB, Leao IC, Lu Y, Wong J, et al. HIV-1 p55Gag encoded in the lyso-some-associated membrane protein-1 as a DNA plasmid vaccine chimera is highly expressed, traffics to the major histocompatibility class II compartment, and elicits enhanced immune responses. $J$ Biol Chem. 2003;278(39):37926-36.

19. Chikhlikar P, Barros de Arruda L, Agrawal S, Byrne B, Guggino W, August JT, et al. Inverted terminal repeat sequences of adeno-associated virus enhance the antibody and CD8 $(+)$ responses to a HIV-1 p55Gag/LAMP DNA vaccine chimera. Virology. 2004;323(2):220-32.

20. Wilmott P, Lisowski L, Alexander IE, Logan GJ. A User's Guide to the Inverted Terminal Repeats of Adeno-Associated Virus. Human Gene Therapy Methods. 2019;30(6):206-13.

21. Zhu E, Wu H, Chen W, Qin Y, Liu J, Fan S, Ma S, Wu K, Mao Q, Luo C, Qin Y, Yi L, Ding H, Zhao M, Chen $J$. Classical swine fever virus employs the PERK- and IRE1-dependent autophagy for viral replication in cultured cells. Virulence. 2021;12(1): 130-49.

22. Vuono EA, Ramirez-Medina E, Azzinaro P, Berggren KA, Rai A, Pruitt S, Silva E, Velazquez-Salinas L, Borca MV, Gladue DP. SERTA domain containing protein 1 (SERTAD1) interacts with classical swine fever virus structural glycoprotein E2, which is involved in virus virulence in swine. $\mathrm{Vi}$ ruses. 2020; 12(4):421.

23. van Rijn PA, Miedema GK, Wensvoort G, van Gennip HG, Moormann R.J. Antigenic structure of envelope glycoprotein E1 of hog cholera virus. J Virol. 1994; 68(6):3934-42.

24. Lorenzo E, Méndez L, Rodríguez E, Gonzalez N, Cabrera G, Pérez C, Pimentel R, Sordo Y, Molto MP, Sardina T, Rodríguez-Mallon A, Estrada MP. Plasticity of the HEK-293 Cells, related to the culture media, as platform to produce a subunit vaccine against classical swine fever virus. AMB Express 2019; 9(1):139.

25. Zhang H, Chen Z, Du M, Li Y, Chen Y. Enhanced gene transfection efficiency by low-dose $25 \mathrm{kDa}$ polyethylenimine by the assistance of $1.8 \mathrm{kDa}$ polyethylenimine. Drug Deliv. 2018;25(1):1740-5.

26. Schnepp BC, Clark KR, Klemanski DL, Pacak CA, Johnson $P R$. Genetic fate of recombinant adeno- 
associated virus vector genomes in muscle. $J$ Virol. 2003r;77(6):3495-504.

\section{Інвертовані термінальні повтори адено- ассоційованого вірусу-2 посилюють експрессію гену химерного Е2 глікопротеїну вірусу класичної чуми свиней}

Я. О. Похоленко, П. В.Бучєк, М. В. Драгулян, В. А. Кордюм

Мета. Дослідження впливу введення інвертованих термінальних повторів адено-ассоційованого вірусу-2 людини до складу плазмідного вектору на експресію химерного Е2 ВКЧС та імуногенність створених кандидатних маркованих ДНК-вакцин проти класичної чуми свиней. Методи. Аналіз експресії химерних білків в клітинах лінії НЕК293 проводили за допомогою конфокальної лазерної скануючої мікроскопії, проточної цитофлуориметрії та вестерн блот аналізу. Наявність антитіл, специфічних до Е2 вірусу класичної чуми свиней у сироватці крові імунізованих мишей проводили за допомогою ІФА. Результати. Було продемонстровано, що введення інвертованих термінальних повторів адено-ассоційованого вірусу-2 до складу плазмідного вектору призводить до значного посилення експресії цільового антигену в клітинах лінії НЕК293 in vitro, не збільшуючи одночасно тривалість збереження трансгену. Значно більш високі титри антитіл, специфічних до химерного Е2 вірусу класичної чуми свиней, були індуковані вакцинацією експресійним вектором, що містить інвертовані термінальні повтори адено-ассоційованого вірусу-2. Висновки. Введення до складу векторної конструкції кандидатної маркованої ДНК-вакцини проти класичної чуми свиней послідовностей інвертованих термінальних повторів адено-ассоційованого вірусу-2 призводить до збільшення як рівня експресії химерного трансгену, так і інтенсивності гуморальної імунної відповіді на вакцинацію.

К л ю ч о в і с л о в а: кандидатна маркована ДНКвакцина, класична чума свиней, ITR AAV-2, гуморальна імунна відповідь

\section{Инвертированные терминальные повторы адено-ассоциированного вируса-2 усиливают экспрессию гена химерного Е2 гликопротеина вируса классической чумы свиней}

\author{
Я. А. Похоленко, П. В. Бучек, М. В. Драгулян, \\ В. А. Кордюм
}

Цель. Исследование влияния введения инвертированых терминальных повторов адено-ассоциированого вируса-2 человека в состав плазмидного вектора на экспрессию химерного Е2 вируса классической чумы свиней и иммуногенность созданных кандидатных маркерных ДНК-вакцин против классической чумы свиней. Методы. Анализ экспрессии химерных белков в клетках НЕК293 проводили с помощью конфокальной лазерной сканирующей микроскопии, проточной цитофлуориметрии та вестерн блот анализа. Наличие антител специфических к Е2 вируса классической чумы свиней в сыворотке крови иммунизированных мышей проводили с помошью ИФА. Результаты. Было продемонстрировано, что присутствие инвертированых терминальных повторов адено-ассоциированого вируса-2 в составе плазмидного вектора приводит к значительному усилению экспрессии целевого антигена в клетках линии НЕК293 in vitro, не увеличивая при этом длительность персистенции трансгена. Значительно более высокие титры антител, специфичных к химерному Е2 вируса классической чумы свиней, были индуцированы вакцинацией экспрессионным вектором, содержащим инвертированые терминальные повторы адено-ассоциированого вируса-2. Выводы. Введение в состав векторной конструкции кандидатной маркированной ДНК-вакцины против классической чумы свиней последовательностей инвертированых терминальных повторов адено-ассоциированого вируса-2 приводит к увеличению как уровня экспрессии химерных трансгенов, так и интенсивности гуморального иммунного ответа на вакцинацию.

К л юч е в ы е с л о в а: маркерная ДНК-вакцина, классическая чума свиней, ITR AAV -2, гуморальный имунный ответ 